\title{
IRK FERENC
}

\section{Viktimológia, közösségi és szituációs bünmegelőzés}

\begin{abstract}
A hagyományos álláspont - már amióta elkezdtek a tettes mellett a sértettel is foglalkozni - azt a szemléletet teszi magáévá, hogy valamely cselekmény szereplői között egyik oldalon foglal helyet a bünös, a másikon az áldozat. Ebben a szemléletmódban az áldozat felé fordulás (Opferorientierung) egyet jelent a tettessel való szembefordulással. Csak lassan változik a helyzet olyan irányba, amely a tettes és az áldozat helyzetének kölcsönös megértéséhez vezet. A ,zéró tolerancia” csupán vontatottan épül le, s adja át a helyét az emócióktól sem mentes párbeszédnek.'

Magam Peter-Alexis Albrecht kérdésfeltevésével és a rákövetkező indokolásokkal értek egyet. A kérdés így szól: vajon a viktimológia eddigi művelésével eljutottunk-e a tettes-áldozat viszony megértésének a végső stádiumához, vagy ez inkább pusztán az első lépés egy hosszú úton? Hajlok afelé folytatja gondolatmenetét Albrecht -, hogy még csupán a kezdeteknél tartunk. Az elmúlt időszak fejleményei még csak annak a következtetésnek a levonásához vezették el a szakemberek (és részben a laikusok) többségét, hogy különféle (többnyire racionális) megfontolásokból értelmes és hasznos dolog az elkövető és a sértett kiegyezésére erőfeszítéseket tenni. Ennek jellemző előfeltétele, hogy a tettes lássa be hibáját és legyen kész tevékeny megbánást mutatva részt venni a sértett kártalanításában. A sértett pedig ugyancsak próbáljon meg - a sérelmeit keretek közé szorítva - ebben a folyamatban részt venni. Afelól ne legyen illúziónk - mondja Albrecht -, hogy a tettes-sértett kiegyezést a folyamatban részesek bármelyike részéről valamiféle humánus és szociálpedagógiai motívum vezérelné. A tényleges indok ennél sokkal hétköznapibb: a büntető igazságszolgáltatás jogszerü befejezésére nehezedő adminisztratív nyomás a valódi hajtóerő. ${ }^{2} \mathrm{Az}$ előbbi megfogalmazással nem áll szemben, mert szintén praktikus szempontra utal Barabás Tünde véleménye. Számára ,úgy tünik, a XXI. században a jogalkotó és a jogalkalmazó, a bünmegelözés és a bünüldözés szerveinek figyelme - az elkövetökre irányuló lehetöség kimerülésével, jobb hiján - a büncselekmény közvetlen érintettje, az
\end{abstract}

1 Vö. Winfried Hassemer - Jan Philipp Reemtsma: Verbrechensopfer. Gesetz und Gerechtigkeit. C. H. Beck Verlag, München, 2002, S. 63.

2 Peter-Alexis Albrecht: Kriminologie. 2. Auflage. C. H. Beck Verlag, München, 2002, S. 400. 
áldozat irányába mozdul el, elismerve a sértettek számos jogát, és ismét erösitve poziciójukat"”.

\section{A visszaeső áldozatokról}

E helyütt célszerü utalni a sokak szerint a viktimológia ,atyjának” tekintett Hans von Hentig tipológiájára, illetve az abból levont következtetésére. E szerint az áldozat - bizonyos értelemben - kialakítja és meghatározza a bünözőt. Felismerte a hely, illetve a szituáció szerepét is az áldozattá válásban. Szólt az úgynevezett áldozati zónákról, amelyek megkönnyítik a bủnözők és áldozataik találkozását (például szórakozóhelyek, éjszakai lokálok, kártyabarlangok, bizonyos üdülöövezetek stb.). ${ }^{4}$ Bár az utóbbi évtizedek kutatásai a korábban kialakított áldozati tipológiákat meghaladták, ennek ellenére azonban Barabás úgy véli, hogy egyrészt ,, vannak olyan áldozatok, akik valamilyen strukturális vagy viselkedési sajátosságuk következtében válnak áldozattá”, másrészt a gyakorlat ,,azt mutatja, hogy egyes személyek az átlaghoz képest gyakrabban válnak áldozattá, amely kapcsolódhat a sértetti személyiséghez (figyelmetlen, túl bizakodó, feledékeny stb.), egyes körülményeihez (idös, fiatal, sérülékeny, gyermek, beteg), vagy az öt körülvevö környezeti tényezöknek (slumosodó környék, leszakadó, hátrányos, deviáló lakóközösség)"'.

Ezt a vélekedést támasztja alá például a brit Nemzeti Bűnmegelőzési Hivatal által még 1994-ben publikált megfigyelés. ${ }^{6}$ E szerint az 1992-ben áldozattá vált személyek fele visszaesően viktimizált, és ők tették ki az összes büncselekmény áldozatainak a nyolcvanegy százalékát. Közülük négy százalék „krónikus” visszaeső, azaz egy éven belül négyszer vagy annál többször vált büncselekmény áldozatává, $\mathrm{s}$ az összes büncselekmény negyvennégy százalékának ők voltak a sértettjei. Sandra Walklate úgy véli, hogy e személyek vonatkozásában lehetetlen hatékony bünmegelőzést folytatni.?

\footnotetext{
3 Barabás A. Tünde: Áldozatok és igazságszolgáltatás. Országos Kriminológiai Intézet, Budapest, 2014, 7. o.

4 Legutóbb idézi Barabás A. Tünde: Uo. 19. o. A főbb áldozati tipológiákról lásd Uo. 19-23. o. 5 Uo. 22-23. o.

6 National Board for Crime Prevention. Wise After the Event: Tackling Repeat Victimisation. Home Office, London, 1994

7 Sandra Walklate: Imagining the Victim of Crime. McGaw Hill Open University Press, London, 2007, p. 77.
} 
Korinek László felhívja a figyelmet arra, hogy „az áldozatoknak a büncselekmények elkövetésében, egyáltalán: a kriminalitásban játszott szerepe kezdettöl fogva megosztotta és megosztja a témával foglalkozó kutatókat”. Azt azonban bizonyítottnak tekinthetjük, hogy ,az elkövetés tipikusan interakció, nem pedig egyoldalú és egyirányú emberei megnyilvánulás következménye"». Korinek behatóan ismerteti az áldozati tipológiákat, továbbá az áldozatnak a büncselekmény létrejöttében való közrehatásáról kialakult nézeteket. ${ }^{9}$ E sorból néhány szempont kiemelése a választott téma okán helyénvalónak tünik. Az elmúlt század hetvenes éveiben különösen élénk empirikus vizsgálatok folytak a világ számos országában. A belölük levont következtetések széles skálán mozogtak. Menachem Amir például saját kutatásaira, továbbá Marvin Wolfgang és Hans von Hentig nézeteire támaszkodva azt állította, hogy az áldozat az esetek igen jelentős részében nem csupán egyik közreható tényezője, hanem éppenséggel elsődleges kiváltó okozója az ellene elkövetett erőszakos nemi közösüléseknek. „Ez azt jelenti, hogy az egyébként gyakran előforduló áldozati mulasztásokon (a célozgatások figyelmen kivül hagyása) vagy aktivitáson (az áldozat elmegy italozni késöbbi támadójával) túlmenöen a sértett olyan kihívó magatartást tanúsit, amely kiprovokálja a szexuális eröszakot." ${ }^{\prime \prime}$ Ezzel egybecseng Mendelsohn azon állítása, amelyik szerint az áldozatoknak van egy jól körülhatárolható csoportja, amelyre az jellemző, hogy ,, valamilyen módon már hatottak az elkövetésre, de nem a büncselekmény elkövetésének szándékával. Ilyen például az a fiatal lány, aki félreérti a hozzá közeledö férfi szándékait, és akaratlanul bátoritja a későbbi támadás elkövetésére." "Il

Az előbbiek értelmében leszögezhetjük: valamennyien alkalmasak és képesek vagyunk arra, hogy olyan normasértést valósítsunk meg, amelynek következtében büncselekmények elkövetői sorába kerülhetünk. De még inkább lehetőségünk van arra, hogy a büncselekmények áldozatainak sorát gyarapítsuk. ${ }^{12}$ Sőt az sem kizárt, hogy egyidejüleg mindkét szerepbe besoroltatha-

\footnotetext{
8 Korinek László: Kriminológia I. Magyar Közlöny Lap- és Könyvkiadó, Budapest, 2010, 355. o.

9 Uo. különösen 352-364. o.

10 Menachem Amir: Patterns in Forcible Rape. The University of Chicago Press, Chicago-London, 1971, pp. 259-270.; Idézi Korinek László: i. m. 353. o.

11 Idézi Korinek László: i. m. 359. o.

12 Nem alaptalanul teszi fel a kérdést Sandra Walklate: „Are we all victims now? ” Lásd Sandra Walklate: i. m. 7. o. Az úgynevezett radikális viktimológia képviselöi között vannak, akik úgy vélik, hogy a kockázattársadalom körülményei között a sértetti kör jelentős mértékben kitágul. Furedi jelen körülményeink közepette már egyenesen a szorongás kultúráját látja kialakulni. Frank Furedi: Culture of Fear: Risk Taking and the Morality of Low Expectation. Cassell, London, 1997; Frank Furedi: Culture of Fear: Risk Taking and the Moarlity of Low Expectation. Revised edition, Cassell, London, 2002. Ez
} 
tunk, ami azt jelenti, hogy egyik büncselekmény elkövetésének következményeként leszünk egy másik büncselekmény áldozata, vagy éppenséggel fordítva: áldozati mivoltunk keletkeztet büncselekménybe keveredési (pre)diszpozíciót. ${ }^{13}$ A témakör alapos ismerői ennek fel- és elismerése által meg kívánják haladni azt az egysíkú szemléletet, amelyik egyik oldalon kizárólag bünös tettest, másik oldalon teljesen vétlen áldozatot diagnosztizál. Láthatjuk, hogy a valós helyzet ennél sokkal összetettebb. Ebből pedig az is következik, hogy az áldozatvédelem nem maradhat meg annál a kényelmes poziciójánál, ami lényegében kimerül a sértett sajnálatában és a sértett által elszenvedett kár lehetőség szerinti kompenzálásában. A korszerü áldozatvédelem akkor töltheti be nemes vállalását, ha a már áldozatokká váltaktól begyüjthető tapasztalatokból tanulságokat von le, s ezekkel hozzájárul a társadalmi és a szituációs bünmegelözés hatékonyságához. Ahhoz tehát, hogy e tapasztalatok megfelelő általánosításával mások elkerülhessék azokat a körülményeket, amelyek fokozott áldozati prediszpozíciókat involválhatnak. Az előzőekben a viktimológia bőséges szakirodalmából néhány ilyen lehetöséget villantottam fel.

Számos, részben az imént is idézett kutatás alapján azt a tényt tartjuk kiemelten fontosnak, amelyik szerint az emberek életük során korántsem azonos eséllyel lesznek akár büncselekmények elkövetöi, akár az ilyen cselekmények áldozatai. Mind a bünelkövetővé, mind az áldozattá válás vizsgálata során számos ismeret gyült össze, amelyek hasznosítására részint a bünmegelőzéstan, részint az alkalmazott viktimológia berkeiben kerül sor. Azzal azonban ma még szinte senki nem foglalkozik, hogy mit kell tennünk annak érdekében, hogy a rizikótársadalom körülményei között minél több ember, embercsoport, közösség helyt tudjon állni, s minél kevesebben legyenek a szép új világra különösen jellemzö büncselekmények áldozatai.

\section{A preventív alkalmazkodás és a tanulás összefüggéseiről}

Célszerü megbarátkozni azzal a gondolattal, hogy két, mostanában gyakran emlegetett fogalmat a sértetti körben is meg lehet, sőt meg kell tölteni tartalommal. Ezek egyike, hogy olyan világban élünk, amelyikben csak annak

\footnotetext{
a nézet tovább él Mythen és Walklate egyik későbbi publikációjában. Gabe Mythen - Sandra Walklate: Communicating the terrorist risk: harnessing a culture of fear? Crime, Media, Culture: An International Journal, vol. 2, no. 2, 2006, p. 129.

13 Winfried Hassemer - Jan Philipp Reemtsma: i. m. 63. o.
} 
van esélye a környezettel való többé-kevésbé harmonikus együttlétre, aki elfogadja, hogy egy életen át tartó tanulási folyamatnak a részese, s ennek megfelelően alakítja magatartását, azaz ahogy és amilyen gyorsan változik a minket körbevevő világ, olyan gyorsan kell alkalmazkodnunk a korábbitól eltérö környezetünkhöz. Ez azt is jelenti, hogy folyamatosan újra kell tanulnunk a bün megelőzésének lehetőségeit ahhoz, hogy a megváltozott viszonyok között se váljunk új elkövetési formákban megvalósuló valamely büncselekmény áldozatává. Erre amiatt van szükségünk, mert a bünelkövetők is alkalmazkodnak az új lehetőségekhez - csak ők olykor gyorsabban találják meg a szükségleteik kielégítéséhez vezető utat, mint amilyen sebességgel sajátítja el a védekezést akár az állam, akár a polgárok normatisztelö többsége. A másik felismerés, hogy a változásokhoz azok alkalmazkodnak sikeresebben, akik kreatívak. A kreativitás ma kulcsfogalommá vált, mert - ahogyan Sir Ken Robinson fogalmaz - ,létfontosságú személyes biztonságunkra és boldogulásunkra nézve" ${ }^{14}$. Az tekinthető kreatívnak, aki idejekorán ismeri fel azokat a veszélyszituációkat, amelyek károsak lehetnek számára, és a felismerés eredményeként adekvát válaszokat ad rájuk. Már itt jeleznem kell: azzal, hogy az egyén a bünelkövetői kihívásra inadekvát (másként fogalmazva: az adott szituációban nem a lehetséges jó, hanem rossz) választ ad, ez nem jelenti egyúttal sem azt, hogy a kihívás és a válaszreakció között oksági kapcsolat van, sem azt, hogy ha mégis megállapítható az oksági összefüggés, azért a bünelkövetőn kívül a büncselekmény sértettjét eleve felelősnek (pláne bünösnek) kellene tekinteni. Ez a distinkció a helyes bünmegelőzési felfogás szempontjából nagyon fontos, bár olykor negligált tétel.

Az áldozati prevenció lényege tehát nem az áldozat sajnálata, nem az áldozati kártalanitás, hanem deviáns viselkedésének megértésén keresztül a további áldozattá válás megelözése - hangsúlyozza Albrecht. Prevenciós szempontból nem tekinthetők kiútnak azok az erőfeszítések sem, amelyek hatására egy-egy elszenvedett büncselekmény után az áldozat még inkább szorong egy lehetséges következő támadástól, mint annak előtte. Az áldozati sajnálat csak megerősíti benne azt a fatalisztikus szemléletet, hogy mások is úgy vélik: semmit sem tehetett volna az őt ért sérelem bekövetkezésének megelőzéséért, sőt a jövőt tekintve is kiszolgáltatott a rajta kívül álló gonosz erőknek. S noha valóban vannak ilyen esetek, a kriminológiai kutatások azonban azt jelzik: büncselekményfajtánként eltérő gyakorisággal ugyan, de az esetek

\footnotetext{
14 Sir Ken Robinson: Az alkotó tér. Lépj ki a dobozból, mert többre vagy képes, mint gondolnád! HVG Kiadó Zrt., Budapest, 2011, 26-27. o. [HVG Könyvek.] Már a monográfia alcíméből is felsejlik, hogy a szerző szerint a kreativitás tanulható.
} 
többségében az áldozatnak lett volna (reális!) lehetősége arra, hogy az öt ért sérelmet megelözze. ${ }^{15}$

Kérdésként merülhet fel, hogy sértetti részről mi tekinthető deviáns viselkedésnek ${ }^{16}$. A válasz általános szinten úgy adható meg, hogy e viselkedési körbe sorolható valamennyi olyan magatartás, amelyik valamely konkrét szituációban nem felel meg, noha elvileg megfelelhetne annak a kívánalomnak, hogy alkalmas legyen az elkövető általi támadás megelőzésére, vagy ha mégsem, legalább a támadás következményeinek mérsékelésére. A sértetti viselkedés tehát azért deviáns, mert nem szituációadekvát. Aligha véletlen, hogy a sértett bünmegelőzési lehetőségeinek alapjai az emberek viszonylag széles körét érintő közúti közlekedés körében kerültek - évtizedek során - kimunkálásra. S ezek a fáradozások - a való világ változásai függvényében folyamatosan fejlődnek, alakulnak. Ha nem így volna, ha az emberek milliói az évtizedek folyamán nem tanulták volna meg, miként lehet más hibázására idejekorán felkészülni, s a védekezésnek milyen alkalmas eszközei lennének, akkor ma az utak háborús övezeteknek volnának tekinthetők, s egyetlen biztosítótársaság sem lenne hajlandó részt venni a kárenyhítésben.

\section{Viktimológiai ismeretek alkalmazása a gyakorlatban: a közösségi és szituációs bűnmegelőzésről}

Noha a bünmegelőzés szakirodalmának mennyisége ma már magyar nyelven is csaknem felmérhetetlen ${ }^{17}$, ezúttal mégis szükségesnek látszik néhány vetületével és kapcsolati hálójával foglalkozni.

A bủnmegelőzés talán legfontosabb ismérve magában az elnevezésében ragadható meg. E szerint alapvető feladata annak elérése, hogy ne következzék be büncselekmény. (Ez közhelynek tünhet ugyan, de mint látni fogjuk, vannak, akiknek ez mintha mégsem volna magától értődő.) Megvalósulási formái aszerint különböznek, hogy rövid vagy hosszú távon kívánunk-e a felkínált lehetőségekkel élni. Ennek alapján teszünk különbséget az elsősorban közép- és hosszú távra, valamint a rövid távra lehetőséget nyújtó módszerek

\footnotetext{
15 Peter-Alexis Albrecht: i. m. 400. o.

16 Már a korábbiakban írtakból is az következik, hogy a deviáns viselkedés címkéje nem utal egyúttal sem a bünös viselkedésre, sem valamiféle felelőtlenségre. Csupán azt jelzi, hogy az emberek mértékadó többsége (amelyik a gondos modell magatartását testesíti meg), hasonló helyzetben másképp cselekedett volna, mégpedig úgy, hogy ennek megfelelően a kárkövetkezmény nagy valószínűséggel elmaradt volna.

17 Részletes elemző összegezését lásd például Korinek László: i. m. 459-513. o.
} 
között. Az előbbit nevezzük társadalmi, az utóbbit közösségi és szituációs bünmegelőzésnek. A továbbiakban az utóbb említettekre összpontosítva vizsgáljuk meg a bünmegelőzés és a (lehetséges!) sértett viszonyát. Ezzel létesítünk kapcsolatot bünmegelőzés és viktimológia között.

\section{A közösségi és szituációs bünmegelózés lényegéről}

Korinek László Walter A. Lundenre hivatkozik, aki szerint ${ }^{18}$ a közösségi bünmegelözés lényege, hogy ,, az elkövetö, illetve a lehetséges elkövetö társadalmi közege felelös tagjának magatartásáért, igy tennie is kell annak érdekében, hogy a súlyos normasértés ne következzen be”. Nyomban hozzáteszi azonban, hogy ,,valójában azonban az együttélés nem azonos az igazi közösségek fennállásával. A földrajzi értelemben egymáshoz közel lévö emberek igen gyakran nem ismerik egymást, igazán nincs közük egymáshoz. Márpedig közösség nélkül értelemszerüen nem képzelhetö el közösségi bünmegelözés." Windt Szandra - az imént kifejtett gondolatokat szinte tovább folytatva - pedig azt hangsúlyozza ${ }^{19}$, hogy ,, a legfontosabb feladat a közösségi megelözésben a cselekvö részvétel, a felelösségérzet felismerése és a tevékeny hozzájárulás". Itt utalok arra, hogy Windt az iskolát a közösségi bünmegelözés olyan kiemelt színtereként tartja számon, amely jelentős feladatot vállalhat a bünmegelőzés e formájában. ${ }^{20}$

A szituációs bünmegelözés „,alapfilozófiája”, hogy a bünözés visszaszorítása elsősorban a bünalkalmak csökkentésén keresztül érhető el. ${ }^{21}$ Windt ehhez hozzáteszi, hogy „, a szituációs bünmegelözés az elkövetőröl egyre inkább az áldozattá válás megelözésére, a szituációra helyezi a hangsúlyt" ${ }^{\text {,22. }}$.

Látszólag talán lényegi eltérés fedezhető fel a közösségi és a szituációs bünmegelőzés között. Windt ezzel kapcsolatban azt hangsúlyozza, hogy a kettő kiegészíti egymást. Úgy fogalmaz, hogy egymás nélkül e két prevenciós forma félkarú óriás. „A közösségi és a szituációs bünmegelözés elemei csak

\footnotetext{
18 Uo. 464. o.

19 Windt Szandra: A második generációs CPTED-ről. In: Barabás A. Tünde (szerk.): Tanulmányok Irk Ferenc professzor 70. születésnapja tiszteletére. OKRI, Budapest, 2012, 276. o.

20 Uo. 281. o.

21 Irk Ferenc: Szituációs bűnmegelőzés lakóövezetekben. In: Barabás Tünde (szerk.): Épített környezet bünözés - szituációs bűnmegelőzés. A lakótelepi bünmegelőzés alapkérdései. Országos Kriminológiai Intézet, Budapest, 2008, 80. o.

22 Windt Szandra: i. m. 271. o.
} 
együttesen fejtenek ki rövid és hosszú távon is kedvezö, a bünalkalmak csökkentésével és a biztonságérzet növelésével járó hatást. ${ }^{{ }_{23}}$

\section{A bünmegelőzés és a bünüldözés különbözőségéről}

A továbbiakban szükségesnek látszik tisztázni, hogy a bünmegelőzés mivel foglalkozik, és mivel nem. Más megközelítésböl: mi a különbség prevenciós és a büntetöjogias gondolkodás, probléma-megközelitési mód között? Ha felismerjük és elfogadjuk, hogy a két diszciplina alapvetöen eltérö alapokon nyugszik, talán esély nyílik azoknak a megnyilvánulásoknak az eliminálására, amelyek szakmai szempontból elfogadhatatlan, téves elképzeléseket hangoztatnak.

A büntetöjogi felfogás - erőteljes leegyszerüsítéssel - arra a kérdésre ad választ, hogy ha sor kerül a tételes jogban megfogalmazott elvárások megsértésére, akkor e normák megsértéséért ki és milyen mértékben felelős. Valamely konkrét esetben annak megállapítását várja el a jogalkotó, hogy a jog alkalmazója állapítsa meg: történt-e büncselekmény, van-e annak elkövetöje és sértettje, $s$ ha vannak ilyenek, akkor melyik fél és milyen mértékben (esetleg arányban) visel felelősséget a bekövetkezett eredményért? Az előbbi tényfeltárás részkérdése lehet, amire esetleg választ kell kapni, hogy a büncselekmény sértettje közrehatott-e, $\mathrm{s}$ ha igen, akkor miként a sérelmére megvalósuló büncselekményben. A büntetés megállapításában majd ezekre a kérdésekre adott ténymegállapítások is szerepet játszanak mint ügydöntően fontos támpontok.

A bünmegelözés általában is, de a jelen alcímben kiemelt terjedelemben rögzített szemlélete különösen, az előbbitől alapvetően különbözik. Mind a közösségi, mind a szituációs bünmegelözésnek az a lényege, hogy - eltérően a büntetőjogi megközelítéstől - még egy büncselekmény megvalósulása után sem a bizonyítékokat igyekszik feltárni és azok segítségével a büntetőjogi felelösséget bebizonyítani. A bünmegelözés mint rendszerdiszciplina nem válogat a „célszemélyek” között. Ehelyett sajátos eszköztárával - a büncselekmény tipizálható tárgyi és személyi jellemvonásainak függvényében olykor, de nem feltétlenül mindig más-más üzenettel - meg kívánja szólitani mind a lehetséges elkövetöket, mind a potenciális sértetteket, mind a két említett sze-

23 Uo. 274. o.; továbbá Windt Szandra: Szituációs és környezeti prevenció a lakótelepeken. Hat lakótelep bemutatása. In: Barabás Tünde (szerk.): i. m. 154-162. o. 
replö szükebb és tágabb környezetét, így végső soron a társadalmat is. A kriminálprevenció azokat a személyi és tárgyi (környezeti) ismereteket igyekszik rendszerbe foglalni, amelyek segítséget nyújthatnak ahhoz, hogy még a büncselekmény bekövetkezése elött információkhoz juttassa mindazokat [eminensen a sérelem elszenvedésének lehetőségét magában hordozó személy(eke)t, valamint azok szükebb és tágabb környezetét] arról, mit tegyenek, vagy ne tegyenek, azaz hogyan viselkedjenek a büncselekménnyel fenyegető helyzet elkerülése érdekében. Az ilyen ajánlások, büncselekménybe keveredés elkerülését célzó javaslatok természetesen gyakran célirányos üzeneteket hordoznak. Így például valamely ajánlás döntési helyzet elé állíthat egyént, csoportot abban az értelemben, hogy az eddig nem ismert, de az üzenet által már megismert kockázatot vállalja-e vagy eláll tőle. Ettől kezdődően - ha a célszemély „vette” a veszélylehetőségről szóló üzenetet, függetlenül a kockázat büntetö- vagy egyéb lehetséges jogi következményeitől - az egyénnek tudomása van a lehetséges kockázatról, beleértve annak esetleges számára kedvezőtlen következményeiről. ${ }^{24}$ Ezen ismeret birtokában kiszélesedik annak lehetősége, hogy vállalja-e a kockázatot, vagy inkább lemond a számára esetleg hátrányos következményekről. Hogyha a kockázatról tud, tehet is annak érdekében, hogy - a számára felkínálkozó, általa már ismert alternatív lehetöség fennállása esetén (!) - elkerülje a kockázatot, s ezáltal mentesüljön a számára kedvezőtlen következmény(ek)től. Más szavakkal: tehet arról, hogy melyik megoldást választja, amennyiben valamely tett negatív kimenetele valóban bekövetkezik; tehet a számára kedvezőtlen következményeiről is, mert tehetett volna ellene. Az ajánlás üzenetének épp annak kell lennie, hogy tipizálható szituációkban egyik vagy másik fél mit és hogyan tegyen, mit és hogyan tehet, mit és hogyan nem tehet, mit és hogyan ne tegyen. Az ismertetett bünmegelőzési szemlélet nem mosható egybe a korábban csak elnagyoltan bemutatott büntetőjogi felelősségi felfogással, noha a morális felelösség vállalásának megléte vagy hiánya ebben az esetben is (tettesi oldalon evidens módon, az egyéb, a büncselekmény megelőzésével közvetlenül vagy közvetve összekapcsolható szereplö esetében pedig esetlegesen) felmerül, sőt adott helyzetekben kiemelt fontossággal bírhat. Ezért fontos e helyütt kiemelni, hogy a bünmegelőzési stratégiák általában nem szükítik le a prevenció lehetőségét egyik vagy másik lehetséges személyre (bünelkövetőre

\footnotetext{
24 A veszélyeztető cselekmény és a kockázat, a nem vállalható veszélyek, valamint a kockázatvállalás összefüggéseiről lásd legújabban Finszter Géza: A rendészeti veszélyelhárítás. In: Bárd Petra - Hack Péter - Holé Katalin (szerk.): Pusztai László emlékére. Országos Kriminológiai Intézet-ELTE Államés Jogtudományi Kar, Budapest, 2014, 235. o.
} 
vagy a büncselekmény sértettjére), hanem a résztvevők személyi körét kiterjesztik egészen addig, ameddig a büncselekmény szereplöire ez a környezet ráhatással bírhat.

\section{A tettes büntetôjogi felelősségének és a sértetti bűnmegelőzés lehetőségének viszonyáról}

Miért kell erről az evidensnek tűnő tényről egyáltalán szót ejteni? Azért, mert van ezzel ellentétes, az előző alapvetésekből következően egyértelmüen hibás szemléleten alapuló álláspont. Ennek hangoztatói szerint, aki azt firtatja, hogy valaki tehetett-e arról, hogy áldozattá vált, illetve tehetett volna-e az ellen, hogy áldozattá váljon, annak már a kérdésfeltevése hibás, mert ez egyet jelent azzal, hogy az áldozatból akar bünöst kreálni. Mindebből szerintük az a következtetés vonható le, hogy aki a tételes jogot megsértő mellett az áldozati bünelkerülés lehetőségeit is vizsgálja, azt vallja, hogy a tettes mentesülhet a büntetőjogi (és nemcsak büntetőjogi, hanem egyéb jogági, sőt azon túl a morális) felelősség alól, és kizárólag az áldozat tehető felelőssé az ôt ért sérelemért.

$A z$ állitás hibás alapokon nyugszik, mert összekeveri a büntetőjogi és a bűnmegelőzési problémamegközelítést, ezért végkövetkeztetésében is hamis. Szakmailag azt az álláspontot tartom igaznak, amelyik azt vallja, hogy ha a veszélyeztetett személy vagy annak környezete ezeket a - többnyire korábbi büncselekmények tapasztalatain alapuló - javaslatokat ismeri, tud róluk, és mindezek ellenére mégsem fogadja meg, ez nem jelenti egyúttal azt is, hogy ezáltal automatikusan átveszi a jogsértő személytől a felelősséget vagy akárcsak osztozik abban. Amint az az előzőekben röviden bemutatott és nemzetközi szakirodalmon alapuló információkból is kitünik: egy bűncselekmény bekövetkezése után (ha az a bűnüldöző hatóságok tudomására jut és megfelelő módszerekkel bizonyításra kerül) a bíróság fogja megállapítani az elkövetői felelősséget - és esetleg a bủncselekmény elkövetésében a sértetti közrehatást, netán részfelelősséget is. Számos büncselekmény esetében ez az út különféle okok miatt nehezen járható (például a sértett feljelentést tesz ugyan, de a tettest nem sikerül kézre keríteni, vagy a sértett különböző okok miatt meg sem kísérli a feljelentés megtételét). Alappal fogalmazhatunk úgy, hogy ezek az igazságszolgáltató szervek által végzett aktusok bünmegelőzési szempontból úgy jellemezhetők, hogy „eső után köpönyeg”. A büncselekmény megvalósulását megelőző bünmegelőzési erőfeszitések (ha ugyan vol- 
tak egyáltalán ilyenek) nem vezettek sikerre, hiszen a büncselekmény megvalósult. Ezért a szakemberek a bünmegelözés keretei között tesznek kísérletet arra, hogy a tipikus bünelkövetési módok, szituációk és személyek elkerülésének lehetöségére felhivják a figyelmet, és így segitsék a büncselekmények megelözését. Hozzá kell tenni: ha a prevenciós üzenet adekvát, tehát elérte a kiválasztott (potenciális elkövetői vagy sértetti) célcsoportot, akkor már e célcsoportok, ideértve ráhatással bíró környezetüket, tehetnek arról, hogy elfogadják-e, és adott esetben követik-e, szükség esetén alkalmazzák-e a prevenciós javaslatokat, vagy elutasítják őket. Ez azt jelenti, hogy a célszemélyek (emberek, az ő családi, baráti, iskolai, munkahelyi és egyéb környezetüket beleértve) az ismeretek birtokában tehetnek mind arról, ha bünalkalmat felkínáló környezetbe kerülnek (mert már tudnak a kockázatról), s természetesen tehetnek is ellene (mert már azt is tudják, hogy ki hogyan nyújthat segítséget ehhez). Ennek előfeltétele azonban, hogy a veszélyeztetett személyek tudjanak a kockázatokról, ne féljenek tölük, és ne szorongjanak miattuk azért, mert nem ismerik a megelózés és a veszélyelhárítás módját, a sokak által helyesen emlegetett „vészkijáratot”. Kockázattársadalomban minimális elvárás mindenkitől, hogy ezeket a kockázatkerülő viselkedésmódokat tőle telhetően ismerje és másokkal is ismertesse meg. Az ismereteket pedig alkalmazni célszerü attól függetlenül, hogy ha valaki bajba kerül, akkor majd a jogi útvesztőben az elkövető vagy a sértett jelzőjét aggatja-e rá a társadalom, a sértett szükebb vagy tágabb környezete. Az ugyan fontos, ám ma már kevés és drága segítség, ha csak a büncselekmény bekövetkezése után nyúlunk az érintettek hóna alá.

\section{A szituációs bűnmegelőzés gyakorlatának alapelveiről}

A bünmegelözés célcsoportjai ezért számosak, kezdve az absztrakt módon veszélynek kitett társadalomtól, ezen belül a fokozott mértékben veszélyeztetett közösségektől a prevencióban közvetlen és már a konkrét veszéllyel érintettek felé irányuló csoportokon (például a fiatalok esetében pedagógusokon, családokon, szórakozóhelyek vezéregyéniségein) át egészen a potenciális bűnelkövetőkig és a büncselekmények sértettjeiig. Egy-egy megcélzott csoport konkrét problémái határozzák meg, hogy a bünmegelőzés melyik eszköztára látszik legcélszerübbnek a prevenciós hatás eléréséhez.

A szituációs bünmegelözés alapeszméje azonos a baleset-megelőzésével. Leglényegesebbnek azt nevezhetjük, hogy az emberi viselkedés kockázati 
helyzeteket ismerje fel idejében és legyen defenzív, tehát védekezésre felkészült. Ez a következő három elvárás teljesítését jelenti: ${ }^{25}$

1. a kötelezőt mindig;

2. a tilosat sohasem;

3. olykor még a megengedettet sem.

Miért van szükség ennek a beállítódásnak a kialakítására? Azért, mert gyakran a véletlen dönti el, hogy valaki büncselekménybe keveredik-e vagy sem, sőt az is - miként erre már utalás történt -, hogy egy büncselekményben a tettesi vagy a sértetti pozíciót tölti-e be (vagy esetleg mindkettőt).

Most térjünk vissza az iménti három pontban megadott feladatsorhoz! Az első kettő tartalma evidens, azokkal a továbbiakban nem foglalkozunk. Mire van szükség ahhoz, hogy valaki az említett 3. pontban megjelölt feladatnak eleget tudjon tenni? Elsösorban szakszerü információkra. Ezek legszámosabban és a leginkább mértéktartó és az ok-okozati kapcsolatok hálóját is tekintve a legkidolgozottabb formákban az igazságszolgáltatás keretében, e körön belül a bünüldöző szerveknél, eminensen pedig a prevenció iránt számos oknál fogva legérzékenyebb rendőrségnél állnak rendelkezésre. A náluk felhalmozott és összefüggéseiben is értelmezhető tudásanyag megalapozza azt az igényt, hogy a közösségi, még inkább a szituációs bünmegelözésnek a rendörség legyen a motorja. Ezért helyénvaló, ha a rendőrség a feladatot részint magára vállalva, részint javaslattétel formájában célirányosan közremüködik a megelőzésben. $M a ́$ sodsorban az előbbire építkező tréningre, aminek során a veszélyeztetettek (kiemelten a gyermek- és fiatalkorúak, az idősek, a veszélyeztetett környezetben élők) - természetesen kellően általánosított formában - még idejekorán hozzájutnak az egyéni magatartás és az abból fakadó fokozott viktimizációs veszély közötti összefüggések megismeréséhez. Ez - jó kommunikáció esetén - a sikeres veszélytréning szerepét tölti be, ami azt jelenti, hogy az összefüggéseket az egyén interiorizálja. Ebből fakadóan egy a megismerthez hasonló esetben (helyzetben), még ha előzőleg nem is e veszélyek körül jártak a tudással már megkínált személy gondolatai, a korábban a tudatalattiba elraktározódott információk általában „,felélednek”. Ezzel egyidejüleg az egyén már válaszút elé kerül, s korábbi ismeretei birtokában képes önállóan dönteni arról, hogy vállalja-e tettének esetleges kedvezőtlen következményeit, vagy más megoldást keres célja eléréséhez, esetleg lemond arról. ${ }^{26}$ Ismeretlen környezetben, váratlan veszélyhelyzet-

25 Ezeket egyébként akár morális imperatívuszoknak is felfoghatjuk.

$26 \mathrm{Ez}$ a Kurt Lewin által megalapozott (Kurt Lewin: A dynamic theory of personality. McGraw-Hill, New York, 1935; Kurt Lewin: A mezőelmélet a társadalomtudományban. Válogatott elméleti tanul- 
ben általában csak annak van esélye a „vészkijáratot” megtalálni, akinek van lehetősége az adott konkrét helyzetet egy már korábban megismert hasonló helyzettel (szükség esetén a másodperc törtrésze alatt) összehasonlítani, s ennek segítségével képes jó döntést hozni. Erre azért van lehetősége, mert a már korábban megismert (és kellően absztrahálódott) veszélyelhárítási stratégiát a most felmerülő konkrét helyzetben is alkalmazni tudja, annak ellenére, hogy a veszélyszituációk soha nem azonosak, csak egy vagy több közös jellemző folytán kisebb-nagyobb mértékben hasonlítanak egymásra.

A kriminológia tudománya a kezdetektől fogva vizsgálta, hogy milyen szerepet játszik az áldozat a büncselekmények bekövetkezésében. Ezek a kutatások tették lehetővé, hogy a bünmegelözés szerves részévé váljon a potenciális sértettek eligazítása arról, mit tegyenek és mit ne annak érdekében, hogy ne váljanak áldozatokká. Ez a módszer éppúgy megfigyelhető a közlekedés, általában a balesetek kapcsán, mint a vagyon vagy az élet elleni büncselekmények megelőzésére tett javaslatokban és intézkedésekben. Ennek része például annak feltárása, hogy a bünelkövetők általában és különösen (szituációfüggően) milyen körülményeket tartanak vonzónak, olyanoknak, amelyek megléte esetén az átlagosnál kisebb a bünelkövetés lelepleződésének a valószínüsége. A bünalkalom-elemzés nemcsak azt segítheti elő, hogy a bünüldözők sikeresebben leplezzenek le egy tettet és annak elkövetőjét, hanem azt is, hogy különösen olyan cselekmények körében, ahol magas a latencia, a sértettek minél felkészültebbek legyenek egy esetleges támadásra, s az előbb említett ismeretszerzési és -raktározási szemlélet értelmében minél többet tehessenek saját védelmük érdekében. ${ }^{27}$

mányok. Gondolat Kiadó, Budapest, 1972) Dimitri Uznadze-féle beállítódás-elmélet (Dimitri Uznadze: Untersuchungen zur Psychologie der Einstellung. Acta Psychologica, Jg. IV, Nr. 3, 1939) lényege, amit a kriminológiában a szintén grúz tudós Mindia Ugrekhelidze fejlesztett tovább. Mindia Ugrekhelidze: Criminalisation of negligent behaviour and the ontologic structure of crime (methodological aspect). Collected Papers, Moscow, 1984; lásd még erről Viski László: Közlekedési büntet?jog. Doktori értekezés. Kézirat. Budapest, 1972. 704-706. o.; továbbá Irk Ferenc: Kriminológia és rendszerelmélet. Jogtudományi Közlöny, 1974/5.; Irk Ferenc: Információelmélet és közlekedés-kriminológia. Jogtudományi Közlöny, 1974/6.

27 Ezt segíthetik a fizikai támadásoktól különösen veszélyeztetett korcsoportokban már nálunk is elterjedőben lévő veszélyelhárítást elősegítő önvédelmi tréningek és az erre épülő sportágak. Ehhez kívántak segítséget nyújtani azoknak a kisfilmeknek a készítői is, akik a gondtalan szórakozás kockázatos következményeire és azok megelőzésének lehetőségeire kívánták felhívni a figyelmet. Szükségesnek látom ide idézni a kisfilmek szövegét, mert vélhetően többen csak nézték a filmet, de a három színész rövid kommentárját nem hallották, s a jeltolmácsra sem fordítottak figyelmet. Az egyik színész itt http://indavideo.hu/video/Selfie_Spot_1 a következőket mondta: „Az emberek, ha nem ismernek, az öltözködésed és a viselkedésed alapján ítélnek meg és bánnak veled. Felelős vagy önmagadért! Tehetsz róla, tehetsz ellene!” A másik itt http://indavideo.hu/video/Selfie Spot 2: „Szülőként soha nem tudnám feldolgozni, ha baj történne a gyermekemmel. Előzd meg, ami megelözhető! Tehetsz róla, te 
Aki ezt a szemléletmódot elutasítja, az - közvetve - a még ingadozó bünelkövetőket segíti abban, hogy minél nagyobb számban és gátlástalanabbul kövessenek el nehezen leleplezhető büncselekményeket, a sértetteket pedig arra kárhoztatja, hogy - sem maga, sem az egyébként segíteni képes és akaró környezete - továbbra se ismerjék fel azokat a veszélyeket és azok elhárítási lehetőségeit, amelyek tipikusan bátorítják az ilyen tetteket elkövetni szándékozókat.

\section{A bünmegelőzés és az áldozatsegítés viszonyáról}

Összefoglalásként álljon itt egy fontosnak tartott tézis: Ahol kudarcot vall a bünmegelözés, ott és akkor (de csak ott és csak akkor) veszi át helyét a áldozatsegités, aminek természetesen része lehet a visszaeső viktimizáció megelőzésének elősegítése. Súlyos hibának (és egyes esetekben kifejezetten a bünmegelőzést és a potenciális áldozatok prevenciós beállítódását hátráltató tevékenységnek) tartom, amikor a két szakma müvelöinek bármelyike nem hajlandó tudomásul venni, hogy adott körülmények között épp melyiké az illetékesség.

hetsz ellene!” A harmadik pedig itt http://indavideo.hu/video/Selfie_Spot3: „Észrevetted, hogy szórakozni senki se indul egyedül, de aki áldozattá válik, mindig magára marad?! Vigyázzatok egymásra! Tehetsz róla, tehetsz ellene!” (Az különösen elgondolkodtató, hogy az alább csak részben bemutatott forrásokban ezek a személyekhez szóló mondatok mintha nem is léteznének, valamilyen oknál fogva mindenhonnan kimaradtak.) Bár a készítőket és az ő szándékaikat nem ismerem, magam úgy gondolom: a kisfilm egyértelmủ mondatokban fogalmazva elsősorban a büncselekmény áldozata környezetének üzen, azokhoz szól, amelyikhez ő is valamilyen módon tartozik: a szülőnek, a társainak. Felületes (és lehet, hogy elöitéletes) gondolkodásra vall, ha mindebből valaki azt a következtetést vonja le, hogy a megerőszakoltak maguk is, sőt elsősorban ők a felelösek azért, ami velük történt, továbbá, hogy az alkotások nőellenesek. Lásd erre például a következőket: http://feminfo.444.hu/2014/11/23/ ilyen-egy-nemi-eroszak-megelozeserol-szolo-kampany/; http://index.hu/belfold/2014/11/25/aldozathibaztatas/ ; http://444.hu/2014/11/27/a-belugy-szerint-csak-felreertik-a-rendorseg-vitainditonakszant-videoit-a-nemi-eroszakrol/; http://444.hu/2014/11/30/magyarorszagnak-nem-fontos-a-nokugye/. Az különösen sajnálatos, hogy volt olyan párt, amelyik a vitát pártpolitikai „magaslatra” emelte: http://index.hu/belfold/2014/12/21/lmp ne vetitsek kozepiskolasoknak a nemi eroszakrol_szolo_rendorsegi_kampanyfilmeket/ Csak sajnálni lehet, hogy az ombudsman és helyettesei az állásfoglalásuk közzétételét megelőzően (http://www.ajbh.hu/kozlemenyek/-/content/10180/1/-tehetsz-rola-tehetsz-ellene-az-alapveto-jogok-biztosa-es-helyettesei-a-rendorseg-videoklipjerol;jsessionid=D40B24E46D3A26EC6CEC1F9C292581D4) a tudomásom szerint egyetlen „közvélemény-kutatás" adatait és az azokból levonható következtetéseket (lásd itt: http:/hvg.hu/velemeny/20141208 Ne_maszkaljanak_a_nok_ejjel_egyedul\#utm_source $=$ hvg_daily\&utm_medium=email\&utm_campaign $=$ newsletter $2014 \_12 \_08 \&$ type $-i d=H v g D$ aily\&user-id $=715$ AFACC $\&$ amp;utm_content $=$ normal\#3atlbm) vélhetően nem vették figyelembe, $\mathrm{s}$ a videók üzeneteinek lényegét tekintve véleményem szerint szintén téves álláspontra helyezkedtek. 


\section{IRODALOM}

Albrecht, Peter-Alexis: Kriminologie. 2. Auflage. C. H. Beck Verlag, München, 2002 Amir, Menachem: Patterns in Forcible Rape. The University of Chicago Press, Chicago-London, 1971

Barabás Tünde (szerk.): Épített környezet - bünözés - szituációs bűnmegelőzés. A lakótelepi bűnmegelőzés alapkérdései. Országos Kriminológiai Intézet, Budapest, 2008

Barabás A. Tünde: Áldozatok és igazságszolgáltatás. Országos Kriminológiai Intézet, Budapest, 2014

Finszter Géza: A rendészeti veszélyelhárítás. In: Bárd Petra - Hack Péter - Holé Katalin (szerk.): Pusztai László emlékére. Országos Kriminológiai Intézet-ELTE Állam- és Jogtudományi Kar, Budapest, 2014, 225-239. o.

Furedi, Frank: Culture of Fear: Risk Taking and the Morality of Low Expectation. Cassell, London, 1997

Furedi, Frank: Culture of Fear: Risk Taking and the Moarlity of Low Expectation. Revised edition, Cassell, London, 2002

Hassemer, Winfried - Reemtsma, Jan Philipp: Verbrechensopfer. Gesetz und Gerechtigkeit. C. H. Beck Verlag, München, 2002

Irk Ferenc: Kriminológia és rendszerelmélet. Jogtudományi Közlöny, 1974/5.

Irk Ferenc: Információelmélet és közlekedés-kriminológia. Jogtudományi Közlöny, 1974/6.

Irk Ferenc: Szituációs bűnmegelőzés lakóövezetekben. In: Barabás Tünde (szerk.): Épített környezet - bűnözés - szituációs bűnmegelőzés. A lakótelepi bűnmegelőzés alapkérdései. Országos Kriminológiai Intézet, Budapest, 2008, 78-106. o.

Kauzlarich, David - Matthews, Rick A. - Miller, William J.: Toward a Victimology of State Crime. Critical Criminology, vol. 10, 2001

Korinek László: Kriminológia I. Magyar Közlöny Lap- és Könyvkiadó, Budapest, 2010

Lewin, Kurt: A dynamic theory of personality. McGraw-Hill, New York, 1935

Lewin, Kurt: A mezőelmélet a társadalomtudományban. Válogatott elméleti tanulmányok. Gondolat Kiadó, Budapest, 1972

Mythen, Gabe - Walklate, Sandra: Communicating the terrorist risk: harnessing a culture of fear? Crime, Media, Culture: An International Journal, vol. 2, no. 2, 2006

National Board for Crime Prevention. Wise After the Event: Tackling Repeat Victimisation. Home Office, London, 1994

Robinson, Sir Ken: Az alkotó tér. Lépj ki a dobozból, mert többre vagy képes, mint gondolnád! HVG Kiadó Zrt., Budapest, 2011 [HVG Könyvek]

Ugrekhelidze, Mindia: Criminalisation of negligent behaviour and the ontologic structure of crime (methodological aspect). Collected Papers, Moscow, 1984

Uznadze, Dimitri: Untersuchungen zur Psychologie der Einstellung. Acta Psychologica, Jg. IV, Nr. 3, 1939

Viski László: Közlekedési büntetőjog. Doktori értekezés. Kézirat. Budapest, 1972

Walklate, Sandra: Imagining the Victim of Crime. McGaw Hill Open University Press, London, 2007 
Windt Szandra: Szituációs és környezeti prevenció a lakótelepeken. Hat lakótelep bemutatása. In: Barabás Tünde (szerk.): Épített környezet - bűnözés - szituációs bűnmegelőzés. A lakótelepi bűnmegelőzés alapkérdései. Országos Kriminológiai Intézet, Budapest, 2008, 129-171. o.

Windt Szandra: A második generációs CPTED-ről. In: Barabás A. Tünde (szerk.): Tanulmányok Irk Ferenc professzor 70. születésnapja tiszteletére. OKRI, Budapest, 2012, 269-284. o. 